\title{
A CASE REPORT: IgA VASCULITIS
}

\section{Anila Reddy.T, Vineeth Reddy.G, Sharvana Bhava B.S.}

${ }^{1}$ Department of Clinical Pharmacy \& Pharm.D., Vaagdevi College of Pharmacy, Warangal, Telangana, Kakatiya University- 506001, India.

*Corresponding author e-mail: sharvanabhava6@gmail.com

\section{ABSTRACT:}

IgA vasculitis is an intense immunoglobulin-A (IgA) intervened jumble described by vasculitis of the little veins of skin, kidneys, gastrointestinal plot, focal sensory system and lungs (uncommon). Period of beginning fluctuates relying upon the setting off factor and scenes might be intermittent. Diseases are likewise one among the danger variables to bring about IgA vasculitis. Signs and manifestations may incorporate fever, rash, vasculitis, stomach torment.

Key words: IgA Vasculitis, Rash, Fever, Anorexia.

\section{INTRODUCTION:}

This problem portrayed by a summed up vasculitis including the little vessels of the skin, the gastrointestinal (GI) lot, the kidneys, the joints, and, infrequently, the lungs and the focal sensory system (CNS). It has been renamed $\operatorname{IgA}$ vasculitis (IgAV), yet the eponymic name stays in wide use. HSP is the most well-known vasculitis in adolescence, the occurrence diminishing with age [1]. The normal prodrome of HSP incorporates cerebral pain, anorexia, fever. The finding of HSP, as amended by the Pediatric Rheumatology European Society (PRES) in 2008, incorporates the accompanying measures: obvious purpura(mandatory standards) within the sight of in any event one of the accompanying (diffuse stomach torment; any biopsy test demonstrating transcendent IgA affidavit; joint pain or intense arthralgia in any joint; and renal inclusion (any haematuria or proteinuria); and IgA statement in a biopsy test in patients with atypical dispersion of purpura [2,3]. It is an intense immunoglobulin A (IgA)interceded jumble portrayed by a summed up vasculitis including the little vessels of the skin, the gastrointestinal (GI) plot, the kidneys, the joints, and, infrequently, the lungs and the focal sensory system (CNS). It is a subset of necrotizing vasculitis described by fibrinoid annihilation of veins and leukocytoclasis [4-6]. The predominance is tops in kids matured 3-10 years, however the condition is additionally found in grown-ups [7]. It has been accounted for that 24 for every 100000 kids more youthful than 17 years will create HSP and there is a solid ethnic impact on the frequency of the infection, with roughly 70/100,000 instances of kids for each year in Asia. In the Northern half of the globe, the infection happens generally among November and January. The male-to-female proportion is $1.5-2: 1^{[8]}$. This is ordinarily an intense, self-restricted sickness, and therapy is essentially strong. Nonetheless, 33\% of patients have at least 1 repeats. In most of 
youngsters, the result of HSP is amazing. Indications and indications of the illness in youngsters normally resolve inside a few days or months. The main organ deciding long haul grimness is kidney contribution. Up to 30-half of youngsters either have or will create hematuria as well as proteinuria inside 4 a month and a half of the underlying introduction. This is normally gentle and selfrestricting. Be that as it may, roughly $20 \%$ of HSP kids with nephritis (7\% of all HSP cases) will grow either a nephritis or nephrotic condition[9-14]. The etiology stays to be obviously characterized however is believed to be multifactorial, with hereditary, natural, and antigenic parts. Over $75 \%$ of patients report precursor upper respiratory parcel or GI contamination. Various bacterial and viral irresistible specialists have been related with the improvement of HSP, and cases likewise have been accounted for after medication ingestions and inoculations. Medications (eg, ampicillin, erythromycin, penicillin, quinidine, quinine, losartan, and cytarabine, nourishments, horse serum, cold presentation, bug chomps.

\section{METHOD}

The Patient visited MGM Hospital with rashes stomach torment and other related side effects. Overseers assent was seeked and clarified about this case report distribution. The Protocol and Written acknowledgment of them was submitted and got affirmed from Institutional Human Ethics Committee (IHEC).

\section{CASE REPORT}

A male offspring of 8 years of age was conceded in pediatric ward of MGM Hospital with complaints revealed by his mom are low grade fever (15 days), swelling of upper and lower appendages, cough with sputum and petechiae. Laboratory Findings were discovered to be ESR-50mmhr, SGPT-66 IU/L, serum creatinine- $0.5 \mathrm{mg} / \mathrm{dl}, \mathrm{CPK}-141 \mathrm{U} / \mathrm{L}$, BU-25 mg/dl, Hb-10.08 g\%, RBS : 95 mg/dl, USG mid-region nerve bladder and urinary bladder are halfway stretched, CRP - ve , Rf- ve. The patient was assessed to have IgAvasculitis. The patient was treated with $\mathrm{T}$. Prednisolone, T. paracetamol, Syp. Ambrodyl, Calamine cream.

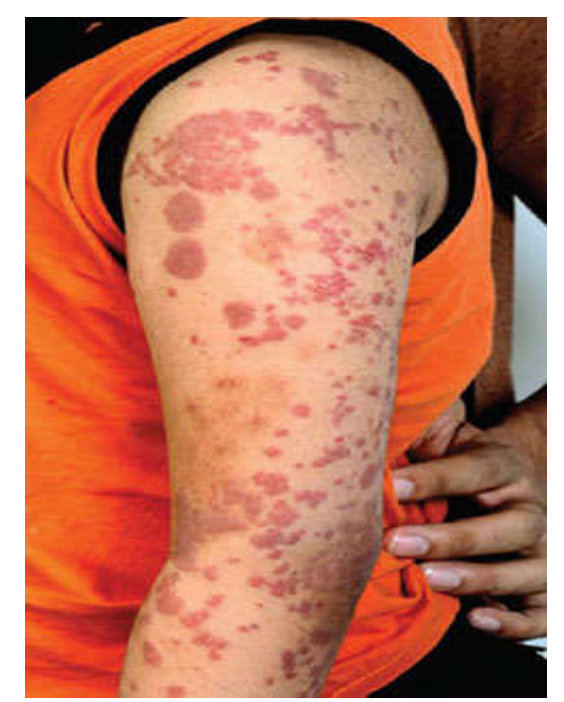

Fig 1: Quiet with IgA-Vasculitis Rash on arms.

\section{DISCUSSION}

In many patients, skin sores are the main indication of IgA Vasculitis. The ejection normally starts as erythematous macular or urticarial injuries, advancing to whitening papules and later to obvious purpura, typically 2-10 $\mathrm{mm}$ in measurement. Different phases of ejection might be available at the same time. Sores ordinarily happen in harvests and may blur more than a few days. Sores commonly are balanced and will in general be circulated in ward body regions, for example, the lower legs and lower legs in more established kids and grown-ups and the back, rear end, furthest points, and upper thighs in little youngsters (in light of the fact that these districts will in general be needy in small kids). The face, palms, soles, and mucous films generally are saved, besides in 
newborn children, in whom facial inclusion may not be uncommon ${ }^{[16]}$.

\section{CONCLUSION}

The treatment given to this patient is as indicated by standard rules and overseer is encouraged to follow the treatment routine likewise until complete fix of the infection. Early determination and brief treatment by steroids can diminish the danger and seriousness of entanglements like myocardial dead tissue, aspiratory drain, pleural emission, GI dying, renal impairment, hematuria, proteinuria, seizures, CNS draining and mono-neuropathies.

\section{ACKNOWLEDGEMENT}

Authors are grateful to the Secretary, Dr. Ch. Devender Reddy, Viswambhara Educational society, for giving us occasion to work and giving essential offices to complete this Research work.

\section{CONFLICT OF INTEREST}

The author(s) confirm that this article content has no conflict of interest.

\section{AUTHORS CONTRIBUTION}

Anila Reddy $\mathrm{T}$ worked in the Hospital in assortment of information, Counseling the patient and their family, and so on, Vineeth Reddy $\mathrm{G}$ planned the records needed for the work. Sharavana bhava B.S. talked about and considered accomplishing this work and arranged the Protocol.

\section{REFERENCES}

[1] Ozen S, Pistorio A, Iusan SM, Bakkaloglu A, Herlin T, Brik R, et al. EULAR/PRINTO/PRES criteria for Henoch-Schönlein purpura, childhood polyarteritis nodosa, childhood Wegener granulomatosis and childhood Takayasu arteritis: Ankara 2008. Part II: Final classification criteria.Ann. Rheum. Dis. 2010. 69:798-806.

[2] Davin JC, Coppo R. Henoch-Schönlein purpura nephritis in children. Nat Rev Nephrol. 2014 Oct. 10 (10):563-73.

[3] Henoch EH. Uber ein eigenthe Form von Purpura.Berl Klin Wochenschr. 1974. 11:641-3.

[4] Blanco R, Martínez-Taboada VM, Rodríguez-Valverde $\mathrm{V}, \quad$ GarcíaFuentes M, González-Gay MA. HenochSchönlein purpura in adulthood and childhood: two different expressions of the same syndrome.Arthritis Rheum. 1997 May. 40(5):859-64.

[5] Szer IS. Henoch-Schönlein purpura. Curr Opin Rheumatol. 1994 Jan. 6(1):25-31.

[6] Trapani S, Micheli A, Grisolia F, Resti M, Chiappini E, Falcini F, et al. Henoch Schonlein purpura in childhood: epidemiological and clinical analysis of 150 cases over a 5-year period and review of literature. Semin Arthritis Rheum. 2005 Dec. 35(3):143-53.

[7] Gardner-Medwin JM, Dolezalova P, Cummins C, Southwood TR. Incidence of Henoch-Schonlein purpura, Kawasaki disease, and rare vasculitides in children of different ethnic origins. Lancet. 2002 Oct 19. 360(9341):1197-202.

[8] Nielsen HE. Epidemiology of SchönleinHenoch purpura. Acta Paediatr Scand. 1998. 77:125-131.

[9] Stewart M, Savage JM, Bell B, McCord B. Long term renal prognosis of HenochSchönlein purpura in an unselected childhood population. Eur J Pediatr. 1988. 147:113-115.

[10] Yoshikawa N, Ito H, Yoshiya K, Nakahara C, Yoshiara S, Hasegawa O, et al. HenochSchoenlein nephritis and IgA IJAPB 
Anila Reddy $T$ et al.

nephropathy in children: a comparison of clinical course.Clin Nephrol. 1987. 27:233-237.

[11] Counahan R, Winterborn MH, White RH, Heaton JM, Meadow SR, Bluett NH, et al. Prognosis of Henoch-Schönlein nephritis in children. Br Med J. 1977. 2:11-14.

[12] Bunchman TE, Mauer SM, Sibley RK, Vernier RL. Anaphylactoid purpura: characteristics of 16 patients who
Int. J. Adv. Pharm. Biotech., 2017; 3(4):1-4 doi.org/10.38111/ijapb.20170304001 progressed to renal failure. Pediatr Nephrol. 1988. 2:393-397.

[13] Saulsbury FT. Epidemiology of HenochSchönlein purpura. Cleve Clin J Med. 2002. 69:87-89.

[14] Makay B, Turkyilmaz Z, Duman M, Unsal E. Mean platelet volume in HenochSchonlein purpura: relationship to gastrointestinal bleeding. Clin Rheumatol. 2009 Oct. 28(10):1225-8.

\section{How to cite this article:}

Anila Reddy. T et al A Case Report: IgA Vasculitis. Int. J. Adv. Pharm. Biotech., 2017; 3(4): 1-4. 